University of Nebraska - Lincoln

DigitalCommons@University of Nebraska - Lincoln

Faculty Papers and Publications in Animal

Science

Animal Science Department

January 1975

\title{
MATERNAL HETEROSIS IN SWINE: REPRODUCTIVE PERFORMANCE AND DAM PRODUCTIVITY
}

R. K. Johnson

University of Nebraska-Lincoln, rjohnson5@unl.edu

I. T. Omtvedt

Oklahoma Agricultural Experiment Station, Stillwater and USDA, EI Reno, OK, iomtvedt1@unl.edu

Follow this and additional works at: https://digitalcommons.unl.edu/animalscifacpub

Part of the Animal Sciences Commons

Johnson, R. K. and Omtvedt, I. T., "MATERNAL HETEROSIS IN SWINE: REPRODUCTIVE PERFORMANCE AND DAM PRODUCTIVITY" (1975). Faculty Papers and Publications in Animal Science. 10.

https://digitalcommons.unl.edu/animalscifacpub/10

This Article is brought to you for free and open access by the Animal Science Department at DigitalCommons@University of Nebraska - Lincoln. It has been accepted for inclusion in Faculty Papers and Publications in Animal Science by an authorized administrator of DigitalCommons@University of Nebraska - Lincoln. 


\title{
MATERNAL HETEROSIS IN SWINE: REPRODUCTIVE PERFORMANCE AND DAM PRODUCTIVITY ${ }^{1}$
}

\author{
R. K. Johnson and I. T. Omtvedt ${ }^{2}$ \\ Oklahoma Agricultural Experiment Station, Stillwater and U. S. Department of Agriculture, \\ El Reno 74074
}

\begin{abstract}
Summary
The objectives of this study were to estimate the heterosis of crossbred gilts for ovulation rate and the maternal heterosis of crossbred gilts for dam productivity. A total of 470 gilts were saved for breeding of which 72 were considered reproductive failures. Estimates of heterosis were made from 193 pregnant gilts slaughtered 30 days postbreeding (106 crossbred and 87 purebred) and 192 litters farrowed (98 three-breed and 94 two-breed cross).

The reproductive failure rate for all gilts was $15.3 \%$ with there being very little difference between purebred and crossbred gilts. Estimates of heterosis for ovulation rate were not significantly different from zero, although crossbred gilts of all breed groups consistently had fewer corpora lutea per gilt than purebreds (13.48 vs 13.03). The embryo survival rate for embryos from crossbred gilts was $9.52 \pm 3.23 \%$ higher than for embryos from purebred gilts. No other estimate of maternal heterosis for traits measured on gilts slaughtered 30 days postbreeding was significantly different from zero, although crossbred gilts consistently had more embryos per litter 30 days postbreeding (10.77 vs 9.95). Three-breed cross embryos were also $.46 \pm .36 \mathrm{~mm}$ longer than two-breed cross embryos.

Crossbred gilts consistently had larger and heavier litters at all ages and raised a larger percentage of their pigs from birth to weaning

\footnotetext{
1 Journal Article 2752 of the Agricultural Experiment Station, Oklahoma State University, Stillwater. Research conducted by the Department of Animal Sciences and Industry (Project 1444) in cooperation with the U.S.D.A. Agricultural Research Service, Southern Region.

${ }^{2}$ Present address: Alabama Agricultural Experiment Station, Auburn University, Auburn 36830.
}

than did purebred gilts. Litters from crossbred gilts contained $.68 \pm .46, .96 \pm .39$ and $.98 \pm$ .36 more pigs and weighed $.69 \pm .54,5.69 \pm$ 1.86 and $10.46 \pm 3.87 \mathrm{~kg}$ more than litters from purebred gilts at birth, 21 and 42 days, respectively. The survival rate from birth to weaning was $4.50 \pm 2.61 \%$ higher for pigs from crossbred gilts than for pigs from purebred gilts.

\section{Introduction}

Reliable estimates of the relative performance for the more promising pure breeds, two-breed crosses and three-breed crosses are needed to select breeds that will be most efficient for a specific type of production. Several studies have shown important differences for many traits among the most common breeds of swine. Recent investigations have demonstrated that several traits exhibit heterosis from crossing and have shown the relative advantage of two-breed crosses compared to purebreds (Smith and McLaren, 1967; Bereskin et al., 1971; Kuhlers et al., 1972; Johnson et al., 1973; Johnson and Omtvedt, 1973b). The most marked advantage of two-breed crosses compared to purebreds is for preweaning pig liveability and dam productivity traits.

In most previous studies, primary emphasis was placed on estimating individual heterosis of the pig. The maternal heterosis of crossbred females or the specific combining ability of breeds in three-breed crosses has seldom been evaluated. There is also very little information available on the heterosis expressed by crossbred gilts for ovulation rate or for embryo development early in the gestation period.

The present study was undertaken to compare the performance of purebred with two-breed cross gilts for reproductive perfor- 
mance, ovulation rate, early embryo development and dam productivity through weaning.

\section{Materials and Methods}

This study involves 470 purebred and two-breed cross gilts of Duroc (D), Hampshire $(\mathrm{H})$ and Yorkshire $(\mathrm{Y})$ breeding. The data come from the 1972 spring and fall farrowing seasons of the Oklahoma swine crossbreeding project. Five to seven purebred boars of each breed were used each season. These boars were produced in the foundation herds maintained at the Experimental Swine Farm at Stillwater. The gilts were randomly selected from litters produced in Phase 1 of the project. Information concerning the foundation herds and the production and subsequent performance of the purebred and two-breed cross gilts used in this study has previously been reported (Johnson et al., 1973; Johnson and Omtvedt, 1973b).

The basic design of Phase II is illustrated in table 1. Each boar was mated to approximately 12 gilts (three of each breed type not represented in the boar). At the time of breeding, two gilts from each mating type from each boar were randomly selected to be carried full term and the remaining gilts were designated for slaughter 30 days postbreeding to evaluate ovulation rates and early embryo development. The total number of sires used of each breed, the number of pregnant gilts of each breeding group slaughtered and farrowed and the number of gilts of each breeding group saved for breeding but resulting in a reproductive failure is shown in table 2 .

In each season the breeding period was of 8-week duration with mating beginning on December 1 for the spring farrowing and June 1 for the fall farrowing. Gilts were bred to farrow at an average age of 1 year. No estimate of physiological age of the gilts was made, however, all gilts were at least 220 days of age at the beginning of the breeding season. Estrus was detected with the assistance of a teaser boar and hand matings were used in each season. Repeat matings were made between 12 and $24 \mathrm{hr}$ after the first service whenever possible.

During breeding and gestation the gilts were maintained in outside dirt lots with 16 gilts per lot. They were individually fed about $1.8 \mathrm{~kg}$ of a $15 \%$ crude protein ration daily. Two weeks prior to breeding daily feed intake was increased by approximately $.68 \mathrm{~kg}$ per day and subsequent to breeding reduced to pre-flushing levels. The feed level was gradually increased in the last 30 days of gestation and the sows were full fed during lactation.

Approximately 30 days postbreeding the gilts predesignated for slaughter were sacrificed on a weekly basis. The reproductive tract of each was removed and corpora lutea counted. Embryos were removed, counted and crownrump length was measured while the embryos were enclosed in the amnion.

Gilts carried to term were brought to the farrowing barn 110 days postbreeding and

TABLE 1. PHASE II MATING SCHEME FOR EACH SEASON IN THE OKLAHOMA SWINE CROSSBREEDING PROJECT

\begin{tabular}{|c|c|c|c|}
\hline Boars & $\begin{array}{l}\text { Mating } \\
\text { typea }\end{array}$ & $\begin{array}{c}\text { Slaughter } \\
\text { postbreeding }\end{array}$ & Farrow \\
\hline 6 Duroc (D) & $\begin{array}{l}18 \mathrm{H} \ldots \mathrm{DxH} \\
18 \mathrm{Y} \ldots \mathrm{DxY} \\
18 \mathrm{HxY} \ldots \mathrm{D}(\mathrm{YxH}) \\
18 \mathrm{YxH} \ldots \ldots\end{array}$ & $\begin{array}{l}8 \\
8 \\
8 \\
8\end{array}$ & $\begin{array}{l}10 \\
10 \\
10 \\
10\end{array}$ \\
\hline 6 Hampshire (H) & $\begin{array}{l}18 \mathrm{D} \\
18 \mathrm{Y} \\
18 \mathrm{DxY} \\
18 \mathrm{YxD} \\
\mathrm{HxY}\end{array}$ & $\begin{array}{l}8 \\
8 \\
8 \\
8\end{array}$ & $\begin{array}{l}10 \\
10 \\
10 \\
10\end{array}$ \\
\hline 6 Yorkshire (Y) & 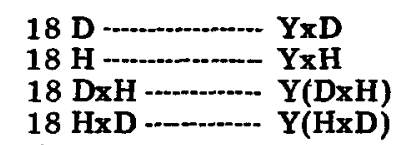 & $\begin{array}{l}8 \\
8 \\
8 \\
8\end{array}$ & $\begin{array}{l}10 \\
10 \\
10 \\
10\end{array}$ \\
\hline$\overline{18}$ & $\overline{216}$ & $\overrightarrow{96}$ & $\overline{120}$ \\
\hline
\end{tabular}

aFirst letter designates breeding of sire and second breeding of dam. 
TABLE 2. TOTAL NUMBER OF SIRES, NUMBER OF PREGNANT GILTS SLAUGHTERED 30-DAYS POSTBREEDING, NUMBER OF GILTS FARROWED AND NUMBER OF REPRODUCTIVE FAILURES FOR EACH BREEDING GROUP

\begin{tabular}{lllccr}
\hline $\begin{array}{c}\text { Breed } \\
\text { of } \\
\text { sire }\end{array}$ & $\begin{array}{c}\text { No. } \\
\text { of } \\
\text { siresa }\end{array}$ & $\begin{array}{c}\text { Breeding } \\
\text { groupb }\end{array}$ & $\begin{array}{c}\text { No. of preg- } \\
\text { nant gilts } \\
\text { slaughtered }\end{array}$ & $\begin{array}{c}\text { No. of } \\
\text { gilts } \\
\text { farrowed }\end{array}$ & $\begin{array}{c}\text { No. of } \\
\text { reproductive } \\
\text { failuresc }\end{array}$ \\
\hline Duroc & $13(11)$ & DxH & 14 & 16 & 7 \\
& & DxY & 16 & 14 & 10 \\
& & D(HxY) & 12 & 17 & 8 \\
Hampshire & $14(11)$ & HxD & 23 & 17 & 3 \\
& & HxY & 12 & 18 & 4 \\
Yorkshire & $16(12)$ & YxD & 9 & 17 & 7 \\
& & YxH & 20 & 18 & 6 \\
& & Y(DxH) & 21 & 15 & 4 \\
Total & & Y(HxD) & 13 & 15 & 4 \\
\hline
\end{tabular}

aFirst number designates the number of sires that were mated to gilts slaughtered and second the number of sires of each breed that produced a litter.

bFirst letter designates breed of sire and second breeding of dam.

CIncludes gits never observed in estrus plus those mated but not pregnant at slaughter or at farrowing.

farrowed in crates. They were moved with their litters to a nursery barn 3 to 7 days after farrowing where they were maintained in the nursery, one litter per pen, until the pigs were weaned at 42 days of age. The pigs were given free access to creep feed and all male pigs were castrated after 21-day weights were taken. Litter size, total litter weight and average pig weight per litter at birth, 21 and 42 days was recorded on each litter.

Gilts that encountered serious illness, disease or injury prior to being slaughtered or farrowed were eliminated from the analyses. Only gilts farrowing at least one live pig and without serious parturition complications were included in preweaning dam productivity data. Litters in which all pigs died from birth to 21 days were not included in the analyses of 21- and 42-day traits but were included in the analysis of pig survival rate. The records of five gilts that were pregnant 30-days postbreeding and eight gilts that farrowed were deleted from analyses for one of the above reasons. All pigs in two litters died prior to weaning.

Heterosis for ovulation rate was estimated by comparing the mean performance of reciprocal crossbred gilts to the mean performance of the purebred gilts that made up the cross. Maternal heterosis was considered as an environmental influence on progeny performance. Estimates were made by the method described by Willham (1968). Estimates of the maternal heterosis of crossbred gilts were made on a within breed of service sire basis by comparing the average performance of crossbred and purebred gilts. The heterosis expressed by crossbred gilts of breed A and breed $B$ is estimated from breeding group means by $1 / 2$ $(\mathrm{AxB}+\mathrm{BxA}-\mathrm{AxA}+\mathrm{BxB})$ where the letters represent the sire and dam breed of the gilts parents. For this comparison to equal the maternal heterosis of crossbred females the following assumptions were made (Willham, 1968);

1. There is no important non-allelic interaction in the crossbred gamete compared with straightbred gametes.

2 . The specific conbining ability of a triple cross is simply the average of the two single cross combining abilities.

3. There is no interaction between the sire contribution and the maternal effect of the dam.

Dickerson (1969) defined the above comparisons in terms of genetic parameters. If the assumptions are true, the above estimate of maternal heterosis measures the deviation in maternal environmental effects due to increased average heterozygosity of $F_{1}$ crossbred females from A-B females, including any deviation due to nonallelic interaction of A with $B$ gametes.

The number of ovulations per gilt was 
considered to be independent of the service sire or breed of sire to which she was mated. The model assumed for the analysis of number of corpora lutea per gilt was: $y_{i j k l}=\mu+r_{i}+s_{j}+d_{k}+$ $(\mathrm{rs})_{\mathrm{ij}}+(\mathrm{rd})_{\mathrm{ik}}+(\mathrm{sd})_{\mathrm{jk}}+(\mathrm{rsd})_{\mathrm{ijk}}+\bar{e}_{\mathrm{ijkl}}$ where $y_{i j k l}$ represents the number of corpora lutea for the $1^{\text {th }}$ gilt from the $\mathrm{k}^{\mathrm{th}}$ breed of dam and the $j^{\text {th }}$ breed of sire in the $i^{\text {th }}$ season, $r_{i}$ is the effect of the season, $\mathrm{sj}_{\mathrm{j}}$ and $\mathrm{d}_{\mathrm{k}}$ represent the effect of the gilt's sire and dam breed, respectively, (rs) ${ }_{\mathrm{ij}}$, (rd) ${ }_{i k},(s d)_{j k}$ and (rsd) ${ }_{i j k}$ are the respective interactions and $e_{i j k l}$ is a random variable assumed to be independently, normally distributed with mean zero and variance $\sigma^{2}$. Constants for the effects in the model were estimated by least squares procedures and comparisons of interest were made by linear functions of least squares constants.

For all other 30-day postbreeding traits and litter traits from birth to weaning, the mating scheme shown in table 1 involved the mating of purebred gilts of two breeds and crosses between them to a third breed of sire. Unequal subclass numbers and empty cells in some service sires within breed of service sire by breed of dam subclass made fitting a complete model impossible. Hence, the data were divided into the six breed of sire-season subsets. The least squares model fit for each subset was $y_{i j k}=\mu+a_{i}+b_{j}+(a b)_{i j}+e_{i j k l}$ where $a_{i}$ is the random effect of service sire, $b_{j}$ is the fixed effect of breeding of dam, $(a b)_{i j}$ is the interaction between service sire and breed of dam and $e_{i j k}$ is a random normal deviate. The sires by breed of dam interaction within each data subset was nonsignificant $(P>.20)$ for all traits. Therefore, the sums of squares for this interaction were pooled across the six subgroups and tested against the corresponding pooled error mean square. This test failed to detect significance $(P>.20)$ for any trait.

Based on this evidence, the sire by breed of dam interaction effect was assumed negligible. All 30-day postbreeding traits, except number of corpora lutea, and preweaning litter traits were analyzed on a within breed of service sire basis according to the model $y_{i j k l}=\mu+s_{i}+a_{j}(i)$ $+\mathrm{d}_{1}+(\mathrm{sd})_{\mathrm{il}}+\mathrm{e}_{\mathrm{ijkl}}$ where $\mathrm{s}_{\mathrm{j}}$, $\mathrm{d}_{1}$ and (sd) represent the fixed effects of season $(i=1,2)$, breeding of dam $(1=1$ to 4$)$ and their interaction, respectively, $a_{j}(i)$ is the random effect of sires nested within season and $e_{i j k l}$ is a random normal deviate. The $a_{j}(i)$ and $e_{i j k l}$ are assumed independent of each other and are assumed independent and normally distributed with zero mean and variance $\sigma_{S}^{2}$ and $\sigma^{2}$, respectively. The degrees of freedom and sums of squares from the within breed of service sire analyses were then pooled over breeds of service sires. From each within breed of service sire analysis, least squares means were calculated for each breeding type of gilt and the following comparisons were made: crossbred $v s$ purebred gilts, between reciprocal crosses and between purebred gilts. Standard errors of least squares means for each breed type of gilt were computed from the within breed of service sire analysis; however, standard errors of the linear contrasts were calculated from the pooled analyses.

Since all gilts were not slaughtered exactly 30 days postbreeding, the observation for each gilt for average embryo length per litter was adjusted to 30 days of age before being subjected to the above analyses. An adjustment factor was obtained by fitting a model that included the effect of the breeding of gilt and the regression of average embryo length per litter on days pregnant. The quadratic regression coefficient was also estimated but it was very small and nonsignificant and not used in the adjustment.

\section{Results and Discussion}

Reproductive Efficiency. The reproductive status of the 470 gilts selected for mating is presented in table 3 for each breeding group. A total of 72 gilts (15.3\%) were never detected in estrus, were not pregnant when slaughtered or did not farrow. The overall failure rate is very similar to the $13.4 \%$ rate reported by Johnson and Omtvedt (1973b) for purebred Duroc, Hampshire and Yorkshire sows and gilts. The reproductive failure rates of $10.5 \%$ and $15.1 \%$ for purebred Duroc and Hampshire gilts, respectively, is somewhat greater than the failure rate of $7.0 \%$ and $6.0 \%$ previously reported for these breeds (Johnson and Omtvedt, 1973b). The failure rate for Yorkshire gilts of $23.3 \%$ is in good agreement with the rate of $23.8 \%$ reported by these authors.

Evidence of heterosis of reproductive failure was lacking (table 3). None of the specific estimates of heterosis for percent reproductive failure rate was significant $(P>.20)$. Overall, $1.7 \%$ fewer crossbred gilts then purebred gilts were considered reproductive failures.

Ovulation Rate and Early Embryo Development. The analysis of variance for number of corpora lutea per gilt slaughtered 30-days postbreeding is presented in table 4 . None of the effects in the model was significant $(P>$ .05 ). The relatively small breed of sire by breed of dam interaction mean square provides little 
TABLE 3. TOTAL NUMBER OF GILTS SELECTED TO BE MATED AND DISTRIBUTION OF REPRODUCTIVE SUCCESSES AND FAILURES FOR GILTS OF EACH BREED GROUP

\begin{tabular}{|c|c|c|c|c|c|c|c|}
\hline $\begin{array}{l}\text { Breeding } \\
\text { of gilts }\end{array}$ & $\begin{array}{c}\text { No. } \\
\text { selected }\end{array}$ & $\begin{array}{l}\text { No. } \\
\text { slaughtered } \\
\text { pregnant }\end{array}$ & $\begin{array}{c}\text { No. } \\
\text { farrowed }\end{array}$ & $\begin{array}{l}\text { No. } \\
\text { never } \\
\text { mated }\end{array}$ & $\begin{array}{l}\text { No. mated } \\
\text { and opena }\end{array}$ & $\begin{array}{c}\text { Total } \\
\text { no. of } \\
\text { failures }\end{array}$ & $\begin{array}{l}\text { Percent } \\
\text { failure } \\
\text { rate }\end{array}$ \\
\hline $\begin{array}{l}\text { Duroc (D) } \\
\text { Hampshire (H) } \\
\text { Yorkshire (Y) } \\
\text { DxH } \\
\text { HxD } \\
\text { DxY } \\
\text { YxD } \\
\text { HxY } \\
\text { YxH }\end{array}$ & $\begin{array}{l}76 \\
73 \\
73 \\
44 \\
38 \\
44 \\
42 \\
37 \\
43\end{array}$ & $\begin{array}{l}32 \\
31 \\
25 \\
21 \\
13 \\
20 \\
21 \\
12 \\
23\end{array}$ & $\begin{array}{l}36 \\
31 \\
31 \\
17 \\
18 \\
18 \\
15 \\
17 \\
17\end{array}$ & $\begin{array}{r}6 \\
2 \\
10 \\
3 \\
2 \\
1 \\
1 \\
3 \\
1\end{array}$ & $\begin{array}{l}2 \\
9 \\
7 \\
3 \\
5 \\
5 \\
5 \\
5 \\
2\end{array}$ & $\begin{array}{r}8 \\
11 \\
17 \\
6 \\
7 \\
6 \\
6 \\
8 \\
3\end{array}$ & $\begin{array}{l}10.5 \\
15.1 \\
23.3 \\
13.6 \\
18.4 \\
13.6 \\
14.3 \\
21.6 \\
7.0\end{array}$ \\
\hline Total & $\overline{470}$ & $\overline{198}$ & $\overline{200}$ & $\overline{29}$ & $\overline{43}$ & $\overline{72}$ & $\overline{15.3}$ \\
\hline
\end{tabular}

aIncludes all gilts mated but not pregnant at slaughter or at farrowing.

statistical evidence for heterosis for ovulation rate.

Least squares breed group means and estimates of heterosis for ovulation rate are presented in table 5. All crossbred groups had lower ovulation rates than the average of the respective purebreds making the cross. The largest difference was $1.02 \pm .51$ corpora lutea per gilt between Hampshire-Yorkshire crosses and the average ovulation rate for purebred Hampshires and Yorkshires. Overall, purebreds had $.45 \pm .35$ more corpora lutea per gilt than crossbreds. In contrast to results presented here, Squires et al. (1952) reported crossbred gilts from inbred Poland China and Hampshire lines and outbred Durocs had $1.19(\mathrm{P}<.01)$ more ova per gilt than the average of purebreds.

Analyses of Variance - Litter Traits. From the pooled analyses of litter traits, the effect of sires within breed of service sire was significant

TABLE 4. ANALYSIS OF VARIANCE FOR NUMBER OF CORPORA LUTEA PER GILT SLAUGHTERED 30-DAYS POSTBREEDING

\begin{tabular}{lrr}
\hline \hline Source & df & \multicolumn{1}{c}{ MS } \\
\hline Season (S) & 1 & 18.59 \\
Breed of sire (BOS) & 2 & 10.37 \\
Breed of dam (BOD) & 2 & 2.07 \\
BOS x BOD & 4 & 5.69 \\
S x BOS & 2 & 6.66 \\
Sx BOD & 2 & 13.86 \\
S x BOS x BOD & 4 & 2.51 \\
Residual & 175 & 5.86 \\
\hline
\end{tabular}

$(P<.05)$ for number of embryos and embryo survival rate to 30 -days postbreeding but the sires mean square was of the same magnitude or smaller than the residual mean square for all other traits. This provides some evidence for variance among sires in early embryo livability. However, if this is true, individual sires should also be important sources of variation for litter size at birth since it is generally accepted that the early life of the embryo is the most critical period. An analysis involving all two-way cross litters produced in the first two phases of this project (all two-way litters in the present study were included) with 67 sires, 167 gilts siaughtered and 176 gilts farrowed resulted in significant sire effects for average embryo length per litter 30-days postbreeding and average pig birth weight per litter $(P<.05)$ and for number of embryos per litter 30-days postbreeding $(\mathrm{P}<.10)$ (Johnson and Omtvedt, 1973a). Reddy et al. (1958), however, found little evidence that the boar influences prenatal death loss. It appears that the influence of boars on litter size and embryo survival needs further investigation.

Season effects were significant $(\mathrm{P}<.05)$ or approaching significance for number of embryos per litter, average embryo length per litter, number of pigs per litter at birth, average pig weight per litter at birth and 42 days and pig survival rate from birth to weaning in each analysis. Averaged overall, gilts mated in the winter for spring litters had 1.06 fewer embryos and average embryo length was $.92 \mathrm{~mm}$ less than those mated in the summer for fall pigs. Spring born litters had .86 fewer pigs at birth, a $10.8 \%$ higher survival rate from birth to weaning and the pigs weighed .08 and $.70 \mathrm{~kg}$ 
TABLE 5. LEAST SQUARES BREED GROUP MEANS AND ESTIMATES OF HETEROSIS FOR NUMBER OF CORPORA LUTEA

\begin{tabular}{lcc}
\hline $\begin{array}{l}\text { Breed } \\
\text { groupa }\end{array}$ & $\begin{array}{c}\text { No. of } \\
\text { gilts }\end{array}$ & Mean \pm SE \\
\hline & $\begin{array}{c}\text { Breed group means } \\
\text { DxD }\end{array}$ & 31 \\
DxH & 21 & $13.31 \pm .44$ \\
DxY & 18 & $13.57 \pm .54$ \\
HxD & 12 & $13.98 \pm .57$ \\
HxH & 31 & $12.57 \pm .71$ \\
HxY & 12 & $13.34 \pm .47$ \\
YxD & 20 & $12.23 \pm .74$ \\
YxH & 23 & $12.89 \pm .55$ \\
YxY & 25 & $13.79 \pm .51$ \\
& Heterosis & \\
DxH \& HxD & 33 & 13.07 \\
DxD \& HxH & 62 & 13.33 \\
Difference & & $-.26 \pm .55$ \\
DxY \& YxD & 38 & 13.49 \\
DxD \& YxY & 56 & $\underline{13.55}$ \\
Difference & & $-.06 \pm .51$ \\
HxY \& YxH & 35 & 12.55 \\
HxH \& YxY & 56 & 13.57 \\
Difference & & $-1.02 \pm .51$ \\
Crossbreds & 106 & 13.03 \\
Straightbreds & 87 & $\underline{13.48}$ \\
Difference & & $-.45 \pm .35$ \\
\hline
\end{tabular}

a First letter represents breed of sire and second breed of dam of glits parents.

more at birth and 42 days, respectively, than fall litters.

The effect of breeding of dam was significant for several traits in the different analyses, but there was virtually no evidence for interaction of season by breeding of dam for any traits. The estimates and discussion of the maternal effects are presented below.

Maternal Effects. Least squares breed group means and standard errors and estimates of maternal effects obtained from gilts slaughtered 30 -days postbreeding are presented in table 6 . Estimates of maternal heterosis were not significantly different from zero for any of the breeding groups. However, crossbred gilts consistently had more embryos, even though they had fewer ovulations, than purebred gilts. Consequently, the average estimate of maternal heterosis for embryo survival rate of $9.52 \pm$ $3.23 \%$ was significant $(P<.01)$. The average advantage for crossbred gilts over purebreds for number of embryos 30 days postbreeding was $.77 \pm .47$, considerably less than the 1.85 pigs per litter advantage reported by Squires et al.
(1952) in crosses involving inbred Poland China and Hampshire lines and outbred Durocs. There was no significant difference between the average embryo length for litters from crossbred and purebred gilts, but overall the embryos from crossbred gilts averaged $.46 \pm .36$ $\mathrm{mm}$ longer than embryos from purebreds. These data provide evidence that the influence of average heterozygosity of crossbred females is an important factor in determining embryo liveability to 30 days postbreeding. The consistency of differences between purebred and crossbred gilts for number of embryos suggest matemal heterosis may also be important for this trait.

Several comparisons among purebred gilts were significant for traits measured 30 days postbreeding. The average embryo length per litter for Duroc gilts was $2.05 \pm 1.00 \mathrm{~mm}$ longer than for Yorkshire gilts and Duroc gilts had $2.09 \pm 1.02$ more embryos than Hampshire gilts. The survival rate for embryos from Duroc gilts was $18.40 \pm 7.03 \%$ higher than for Hampshire gilts. The differences in performance of purebred dams are similar to those reported by Johnson and Omtvedt (1973b) and tend to support their conclusions. Comparisons among reciprocal crossbred gilts were generally small and provide little evidence for reciprocal differences.

Least squares breed group means and standard errors and estimates of maternal effects for preweaning dam productivity are presented in table 7. Duroc-Hampshire cross gilts had significantly $(\mathrm{P}<.05)$ heavier litters at 21 days $(8.97 \pm 3.11 \mathrm{~kg})$ and at 42 days $(13.54$ $\pm 6.47 \mathrm{~kg}$ ) than the average for purebred Duroc and Hampshire gilts. Hampshire-Yorkshire cross gilts exhibited significant negative maternal heterosis for average pig birth weight $(-.10 \pm$ $.05)$. No other estimates of maternal heterosis were significant, however, crossbred gilts of all breeding consistently had larger litters at all ages than purebreds and consequently heavier litters, even though estimates of maternal heterosis for average pig weight per litter were small. With the exception of Hampshire-Yorkshire cross gilts, crossbred gilts also raised a greater percentage of pigs from birth to weaning than purebred gilts.

Overall, crossbred gilts had larger and heavier litters than purebreds at all ages with significant average maternal heterosis observed for litter size at 21 and 42 days $(.96 \pm .39$ and $.98 \pm .38$ pigs, respectively), litter weight at 21 and 42 days $(5.69 \pm 1.86$ and $10.46 \pm 3.87 \mathrm{~kg}$, respectively). Although not significant, survival rate from birth to weaning was higher for pigs 
TABLE 6. LEAST SQUARES MEANS AND STANDARD ERRORS AND SPECIFIC COMPARISONS AMONG MEANS, PRESENTED BY BREED OF SERVICE SIRE, FOR TRAITS OF GILTS SLAUGHTERED 30-DAYS POSTBREEDING

\begin{tabular}{|c|c|c|c|c|}
\hline $\begin{array}{l}\text { Breeding } \\
\text { of gilta }\end{array}$ & No. & $\begin{array}{l}\text { No. of } \\
\text { embryos }\end{array}$ & $\begin{array}{l}\text { Avg embryo } \\
\text { length per } \\
\text { litter, mm }\end{array}$ & $\begin{array}{l}\text { Percent live } \\
\text { embryos of } \\
\text { corpora lutea }\end{array}$ \\
\hline
\end{tabular}

Means and comparisons among means for gilts mated to Duroc sires

\begin{tabular}{|c|c|c|c|c|c|}
\hline $\begin{array}{l}\mathrm{H} \times \mathbf{H} \\
\mathrm{HXY} \\
\mathbf{Y} \times \mathrm{H} \\
\mathbf{Y} \mathbf{X Y}\end{array}$ & $\begin{array}{l}14 \\
12 \\
23 \\
16\end{array}$ & $\begin{aligned} 8.65 \pm & .95 \\
11.13 \pm & .96 \\
10.31 \pm & .74 \\
10.85 \pm & .81\end{aligned}$ & $\begin{array}{l}26.79 \pm \\
27.67 \pm \\
27.97 \pm \\
27.88 \pm\end{array}$ & $\begin{array}{l}.48 \\
.50 \\
.36 \\
.40\end{array}$ & $\begin{array}{l}68.17 \pm 6.39 \\
87.73 \pm 6.48 \\
82.01 \pm 5.00 \\
80.88 \pm 5.48\end{array}$ \\
\hline $\begin{array}{l}\text { Crossbreds-Purebreds } \\
\text { HxH-YxY } \\
\text { HxY-YxH }\end{array}$ & & $\begin{array}{r}.97 \pm .82 \\
-2.20 \pm 1.18 \\
.82 \pm 1.14\end{array}$ & $\begin{array}{r}.49 \pm \\
-1.09 \pm \\
-.30 \pm\end{array}$ & $\begin{array}{l}.61 \\
.89 \\
.88\end{array}$ & $\begin{array}{r}10.35 \pm 5.65 \\
-12.71 \pm 8.17 \\
5.72 \pm 7.90\end{array}$ \\
\hline
\end{tabular}

Means and comparisons among means for gilts mated to Hampshire sires

\begin{tabular}{|c|c|c|c|c|}
\hline $\begin{array}{l}D \times D \\
D \times Y \\
Y \times D \\
Y \times Y\end{array}$ & $\begin{array}{r}12 \\
18 \\
20 \\
9\end{array}$ & $\begin{array}{r}9.70 \pm .97 \\
10.57 \pm .83 \\
10.67 \pm .80 \\
10.87 \pm 1.07\end{array}$ & $\begin{array}{l}29.38 \pm .96 \\
28.39 \pm .80 \\
29.39 \pm .76 \\
27.33 \pm 1.07\end{array}$ & $\begin{array}{l}72.41 \pm 6.72 \\
79.67 \pm 5.58 \\
81.28 \pm 5.30 \\
77.15 \pm 7.49\end{array}$ \\
\hline $\begin{array}{l}\text { Crossbred-Purebred } \\
D \times D-Y \times Y \\
D \times Y-Y \times D\end{array}$ & & $\begin{array}{r}.34 \pm .85 \\
-1.17 \pm 1.33 \\
-.10 \pm 1.03\end{array}$ & $\begin{array}{r}.54 \pm \quad .65 \\
2.05 \pm 1.00^{*} \\
-1.00 \pm .78\end{array}$ & $\begin{array}{r}5.70 \pm 5.89 \\
-4.74 \pm 9.23 \\
-1.61 \pm 7.13\end{array}$ \\
\hline
\end{tabular}

Means and comparisons among means for gilts mated to Yorkshire sires

\begin{tabular}{lrrrrr} 
DxD & 19 & $10.87 \pm$ & .76 & $27.51 \pm .43$ & $82.41 \pm 5.49$ \\
DxH & 21 & $11.68 \pm .77$ & $27.62 \pm$ & .44 & $86.34 \pm 5.59$ \\
HxD & 12 & $10.26 \pm .94$ & $27.76 \pm .54$ & $85.10 \pm 6.61$ \\
HxH & 17 & $8.78 \pm .82$ & $27.15 \pm .46$ & $64.01 \pm 5.85$ \\
Crossbred-Purebred & & $1.15 \pm .76$ & $.36 \pm .59$ & $12.51 \pm 5.25 *$ \\
DxD-HxH & & $2.09 \pm 1.02^{*}$ & $.36 \pm .76$ & $18.40 \pm 7.03 * *$ \\
DxH-HxD & & $1.42 \pm 1.17$ & $-.14 \pm .88$ & $1.24 \pm 8.09$ \\
Overall Crossbred-Purebred & & $.77 \pm .47$ & $.46 \pm .36$ & $9.52 \pm 3.23 * *$ \\
\hline
\end{tabular}

aFinst letter represents breed of sire and second breed of dam of gilts parents; $D=D u r o c, H=H a m p-$ shine, $Y=$ Yorkshire.

$* \mathbf{P}<.05$.

$* \mathbf{P}<.01$.

from crossbred gilts $(4.50 \pm 2.61 \%)$. This suggests the average heterozygosity of crossbred females is an important environmental factor in pig liveability and litter size resulting in larger, heavier litters than litters raised by purebred gilts. Perhaps the fact that crossbred gilts had more pigs per litter but maintained their pigs at the same weight as those from purebred gilts suggests that they also provided a more desirable preweaning nutritional environment.

Purebred Yorkshire gilts had significantly more pigs per litter $(2.43 \pm 1.04)$ and pigs that weighed significantly less $(.21 \pm .07)$ than purebred Duroc gilts. No other comparisons among purebred dams were significant although the differences observed are in general agreement with results presented by Johnson and Omtvedt (1973b).
The average pig weight per litter at birth for DxY cross gilts was $.15 \pm .07 \mathrm{~kg}$ heavier than the average pig weight for $\mathrm{YxD}$ cross gilts. No other reciprocal differences between crossbred gilts were significant and most other estimates were relatively small suggesting little difference in the productivity of reciprocally produced gilts.

The results presented here are in general agreement with reports in the literature comparing litter traits for purebred and crossbred gilts. Crossbred sows have been reported to have litters ranging from .0 to 1.20 more pigs at birth and 1.0 to 1.7 more pigs at weaning than purebred sows (Winters et al., 1935; Robinson, 1948; Chambers and Whatley, 1951; Bradford et al., 1953; Whatley, et al., 1954; Smith and McLaren, 1967). In general these studies also reported little difference in 


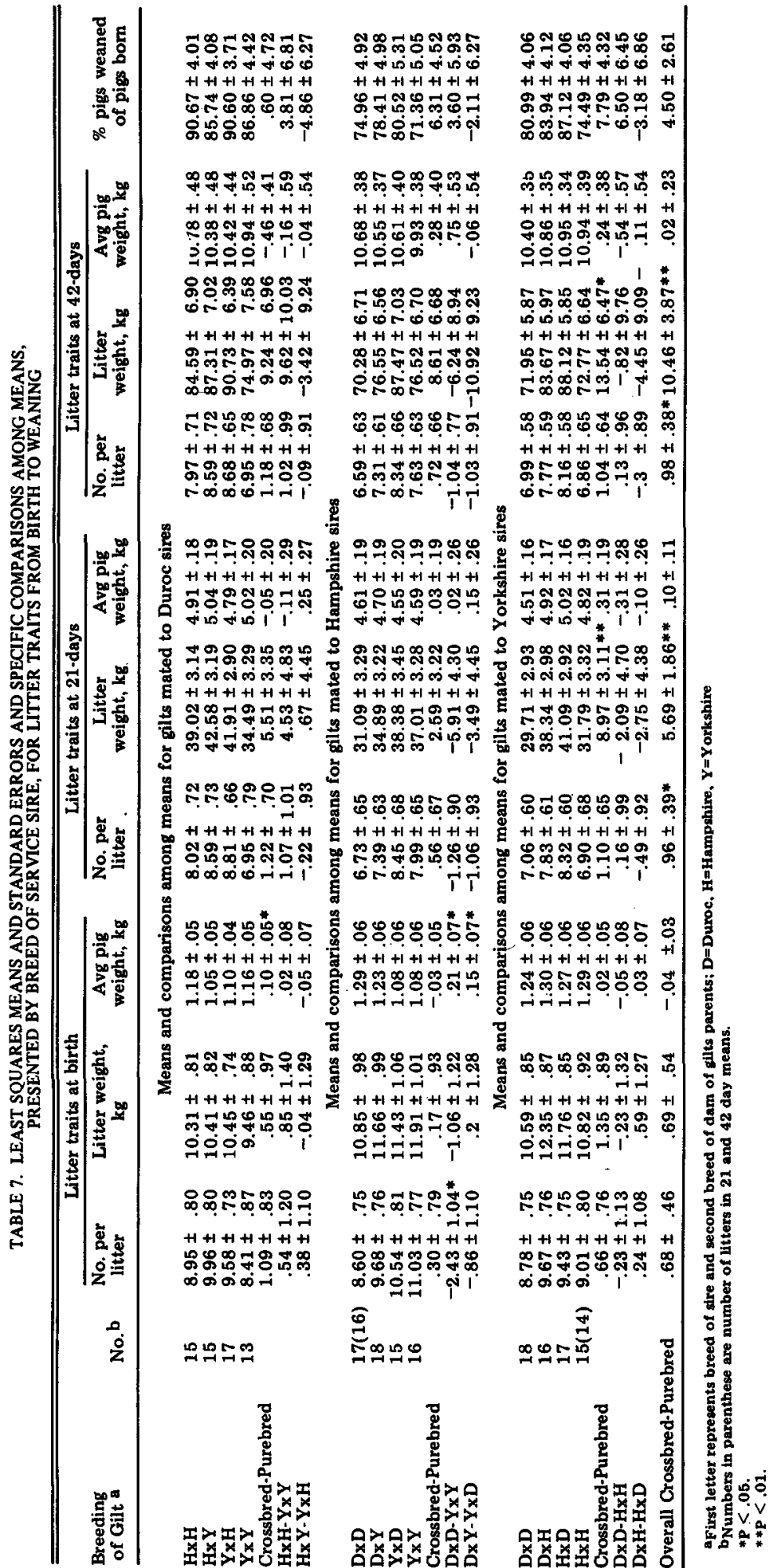


pig weights between two and three-breed crosses. No specific estimates of maternal heterosis are available for comparison purposes.

Pani et al. (1963) found Landrace-Poland crossbred sows from Poland dams to have larger litters and heavier pigs than crossbred sows from Landrace dams although the differences were not significant. In the present study the mean performance of reciprocally produced crossbred females was similar and suggests that deviations due to environmental effects of genotypes of the gilt's dam are in general small and unimportant.

\section{Literature Cited}

Bereskin, B., C. E. Shelby and L. N. Hazel. 1971. Carcass traits of purebred Durocs and Yorkshires and their crosses. J. Anim. Sci. 32:413.

Bradford, G. E., A. B. Chapman and R. H. Grummer. 1953. Performance of hogs of different breeds and from straightbred and crossbred dams on Wisconsin farms. J. Anim. Sci. 12:582.

Chambers, D. C. and J. A. Whatley, Jr. 1951. Heterosis in crosses of inbred lines of Duroc swine. J. Anim. Sci. 10:505.

Dickerson, G. 1969. Experimental approaches in utilizing breed resources. Anim. Breed. Abstr. 37:191.

Johnson, R. K. and I. T. Omtvedt. 1973a. Effect of sire and breed of sire on sow productivity. J. Anim. Sci. 37:235. (Abstr.).
Johnson, R. K. and I. T. Omtvedt. 1973b. Evaluation of purebreds and two-breed crosses in swine: Reproductive performance. J. Anim. Sci. 37:1279.

Johnson, R. K., I. T. Omtvedt and L. E. Walters. 1973. Evaluation of purebreds and two-breed crosses in swine: Feedlot performance and carcass merit. J. Anim. Sci. 37:18.

Kuhlers, D. L., A. B. Chapman and N. L. First. 1972. Estimates of genotype - environment interactions in production and carcass traits in swine. J. Anim. Sci. 35:1.

Pani, S. N., B. N. Day, L. F. Tribble and J. F. Lasley. 1963. Maternal influence in swine as reflected by differences in reciprocal crosses. Mo. Agr. Exp. Sta. Bull. 830 .

Reddy, V. B., J. F. Lasley and D. T. Mayer. 1958. Genetic aspects of reproduction in swine. Mo. Agr. Exp. Sta. Res. Bull. 666.

Robinson, W. L. 1948. Crossbreeding for the production of market hogs. Ohio Agr. Exp. Sta. Res. Bull. 675.

Smith, H. J. and J. B. McLaren. 1967. Performance of breeds and breed crosses of swine. Tenn. Agr. Exp. Sta. Bull. 434.

Squires, C. P., G. E. Dickerson and D. T. Mayer. 1952. Influence of inbreeding, age and growth rate of sows on sexual maturity, rate of ovulation, fertilization and embryonic survival. Mo. Agr. Exp. Sta. Res. Bull. 494.

Whatley, J. A., Ir., D. Chambers and D. F. Stephens. 1954. Using hygrid vigor in producing market pigs. Okla. Agr. Exp. Sta. Bull. 415.

Willham, R. L. 1968. Experimental evaluation of maternal heterosis. Proceedings 1968 Technical Committee Meeting NC-1. Madison, Wisc.

Winters, L. M., O. M. Kiser, P. S. Jordan and W. H. Peters. 1935. A six years study of crossbreeding swine. Minn. Agr. Exp. Sta. Bull. 320. 